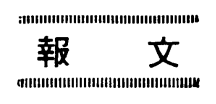

\title{
Fe-Si-Al 系合金の高温における酸化膜およびスケール*
}

\author{
椙 山 正 孝** 中 山忠 行*** \\ On the Oxide Films and Scales of Fe-Si-Al System \\ Alloys at High Temperature
}

Masataka Sugiyama and Tadayuki Nakayama

The present authors observed the oxide films and scales produced on the surface layers of $\mathrm{Fe}$ $\mathrm{Si}-\mathrm{Al}$ alloys (ca. $1 \sim 6 \% \mathrm{Si}-1 \sim 7 \% \mathrm{Al}$ ) by using the transmission electron diffraction, X-ray diffraction and metallugical microscopic methods, when the alloys came into contact with air at $700^{\circ} \sim 1200^{\circ} \mathrm{C}$. And thereby the authors detected the special heatresisting films consisting of amorphous $\mathrm{SiO}_{2}$ or fine $\mathrm{Al}_{2} \mathrm{O}_{3}$ crystals which were formed on the surfaces of $\mathrm{Fe}-\mathrm{Si}-\mathrm{Al}$ alloys in the earliest stage of oxidation at $700^{\circ} \mathrm{C}$ and $1000^{\circ} \mathrm{C}$ (Table 2). It was also clarified by X-ray diffraction measurments that fine $\alpha$ -
$\mathrm{Al}_{2} \mathrm{O}_{3}$ crystals are formed on the surfaces of ca. $6 \% \mathrm{Al}-\mathrm{Si}-\mathrm{Fe}$ alloys (FSA 3 and 6 ), and moreover, that ca. $6 \% \mathrm{Si}-\mathrm{Al}-\mathrm{Fe}$ alloy is covered with $\mathrm{SiO}_{2}$ crystals at $1100^{\circ} \mathrm{C}$. Besides iron oxides, the $\mathrm{X}$-ray diffraction patterns of the oxide scales produced on the Fe-Si-Al alloys at $1200^{\circ} \mathrm{C}$ illustrate the existence of $\mathrm{Fe}_{2} \mathrm{SiO}_{4}$ crystal layers. The eutectic point of $\mathrm{Fe}_{2} \mathrm{SiO}_{4}$ and $\mathrm{FeO}$ phases is $1170^{\circ} \mathrm{C}$, therefore it should be reasonable to consider that the heatresisting nature of these alloys fall remarkably at $1200^{\circ} \mathrm{C}$.

\section{1. 緒}

$\mathrm{Fe} に \mathrm{Si}$ と同時に $\mathrm{Al}$ を添加した $\mathrm{Fe}-\mathrm{Si}-\mathrm{Al}$ 系合金 は一般にすぐれた耐高温酸化性を有し，Scheil および Kiwit ${ }^{1)}$ によればあらゆる比率の $\mathrm{Al}$ と $\mathrm{Si}$ を含えだ Al-Si 鋼について耐酸化性合金が得られると報告してい る。しかしながら三島および椙山块はこの系の数種の合 金について耐酸化限界温度を調べた結果，約 2 ～3\% $\mathrm{Al}-2 \sim 3 \% \mathrm{Si}-\mathrm{Fe}$ 系合金では $1100^{\circ} \mathrm{C}$ 付近で，また $\mathrm{Si}$ 含量の多い約 $3 \% \mathrm{Al}-5 \% \mathrm{Si} \cdot \mathrm{Fe}$ 系合金では $1150^{\circ} \mathrm{C}$ 付 近で耐高温酸化性を失うことを見出している。すなわち 同 $\mathrm{Si}$ 含量の $\mathrm{Fe}-\mathrm{Si}$ 系合金に比して Fe-Si-Al 系合金の 耐酸化限界温度がむしろやや低目に見出されたが，その 原因はいまだ明らかにされていない。

本研究においては鉄鋼に約 1〜6\% Si と同時に約 1〜 $7 \% \mathrm{Al}$ を添加した Fe-Si-Al 系合金について, 空気中 高温酸化の初期 $\left(700^{\circ} \mathrm{C}\right.$ および $\left.1000^{\circ} \mathrm{C}\right)$ に含金表面を 被覆した酸化膜の電子回折透過観察を行ない, 主として 酸化初期にその形成が予想され，乙かも爾後の合金の耐 酸化性に著しく寄与すると思われる $\mathrm{SiO}_{2}$ あるいは $\mathrm{Al}_{2} \mathrm{O}_{3}$ など低電気伝導度の特別な耐酸化性皮膜の検出を試み た。さらに空気中 $1100^{\circ} \mathrm{C}$ およ゙ $1200^{\circ} \mathrm{C}$ の高温での酸 化スケールについて X 線回折ならびに顕微鏡による観

\footnotetext{
* 昭和 34 年 4 月 日本金属学会第 44 回講演大会発表

** 東京大学工学部冶金学教室

*** 早䅛田大学第一理工学部金屈工学科
}

察を行ない，合金中の成分元素含量および酸化温度がス ケール構造に及ばす影響を明らかにすると同時に，耐高 温酸化性との関係を竸明し，なかんずく本系合金の耐酸 化性劣化の原因を究明した。

\section{2. 供試々料および実験}

本研究に用いた Fe-Si-Al 系合金はいずれも電解 $\mathrm{Fe}$ (99.97\%)，金属 Si (99.8\%) ならびに $99.997 \% \mathrm{Al}$ を 用いて, 真空度約 $10^{-4} \mathrm{mmHg}$ の高周波加熱炉で溶解 し，同じ真空中でシェル鋳型中に鋳造したものである。 このようにして総量各 $200 \mathrm{~g}$ ほどの 9 種の合金試料を作 成したが，その程類と wt\% で表わした $\mathrm{Si}$ および $\mathrm{Al}$ の含量を第 1 表に揭げる。これら各鋳造合金はいずれも

第 1 表 供試 $\mathrm{Fe}-\mathrm{Si}-\mathrm{Al}$ 系合金

\begin{tabular}{|c|c|c|c|c|c|c|c|c|}
\hline 種類 & $\mathrm{Si} \%$ & Al\% & 種類 & Si\% & Al\% & 種類 & Si\% & $\mathrm{Al} \%$ \\
\hline $\begin{array}{l}\text { FSA } 1 \\
\text { FSA } 2 \\
\text { FSA } 3\end{array}$ & $\begin{array}{l}0.82 \\
0.82 \\
1.07\end{array}$ & $\begin{array}{l}0.91 \\
2.36 \\
6.39\end{array}$ & $\begin{array}{ll}\text { FSA } & 4 \\
\text { FSA } & 5 \\
\text { FSA } & 6\end{array}$ & $\begin{array}{l}3.00 \\
3.01 \\
3.16\end{array}$ & $\begin{array}{l}1.00 \\
2.86 \\
6.07\end{array}$ & $\begin{array}{l}\text { FSA } 7 \\
\text { FSA } 8 \\
\text { FSA } 9\end{array}$ & $\begin{array}{l}5.82 \\
5.67 \\
6.37\end{array}$ & $\begin{array}{l}1.35 \\
3.15 \\
6.61\end{array}$ \\
\hline
\end{tabular}

鋳造歪の除去と組成均質化の目的で，あらかじめ約 $1150^{\circ} \mathrm{C}$ で約 $2 \mathrm{hr}$ 焼鈍後炉冷された。その後炉冷合金 から直径約 $15 \mathrm{~mm}$, 厚さ $5 \mathrm{~mm}$ の試片を採取し, エメ リ一紙 (0 番) 仕上後メタノール, エーテルの順に脱脂 洗浄し, 乾燥してから酸化した。酸化はいずれもあらか じめ所定の酸化温度に加熱保持した横型ェレマ炉の大気

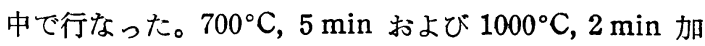
熱で試片表面を被㠅した初期酸化膜を $1 \mathrm{cc} \mathrm{Br}_{2} / 50 \mathrm{cc}$ 
$\mathrm{CH}_{3} \mathrm{OH}$ の常温溶液を用いて刽離した後，再びメタノー ルで洗浄後 Pt ネットに張り約 $80 \sim 90 \mathrm{kV}$ の加速電子 線で透過観察した。

また $1100^{\circ} \mathrm{C}, 7 \mathrm{hr}$ および $1200^{\circ} \mathrm{C}, 3 \mathrm{hr}$ 空気中加熱 で合金表面に形成した酸化物スケールの断面組織を光学 顕微鏡で観察すると同時に，これを合金表面から機械的 に涂離し, 約 300 メッシュの粉末として後 X 線デイフ ラクトメーターによって酸化物の同定を試みた。なお対 陰極は $\mathrm{Fe}$ を用い $\mathrm{Mn}$ でフィルターして，管球電圧お よび電流をそれぞれ $30 \mathrm{kV}, 8 \mathrm{~mA}$ とし $2^{\circ} / \mathrm{min}$ の走査 速度で範囲 $\left(2 \theta^{\circ}\right)$ を $20 \sim 95^{\circ}$ にとってチャート紙に自 記記録させた。

\section{3. 初期酸化膜の観察}

\section{(1) 約 1\% Si-Al-Fe 系合金 (FSA 1 3)}

約 1\% $\mathrm{Si}$ とともに約 1 6\% Al を含有した FSA 1 3 9空気中 $700^{\circ} \mathrm{C}$ および $1000^{\circ} \mathrm{C}$ 初期酸化膜は，い ずれも rhombohedral 型結晶の $\alpha-\mathrm{Fe}_{2} \mathrm{O}_{3}$ を主体とした 酸化物からなり, FSA 2 の $1000^{\circ} \mathrm{C}$ および FSA 3 の $700^{\circ} \mathrm{C}$ ならびに $1000^{\circ} \mathrm{C}$ 酸化膜中には, $\alpha-\mathrm{Fe}_{2} \mathrm{O}_{3}$ およ び $\mathrm{Fe}_{3} \mathrm{O}_{4}$ など酸化鉄以外に合金表面に接して形成した $\gamma$-あるいは $\alpha-\mathrm{Al}_{2} \mathrm{O}_{3}$ からなる薄膜の存在が認められた (第 2 表)。それに反してこれら $\mathrm{Al}_{2} \mathrm{O}_{3}$ 皮膜の形成を見

第 2 表 $\mathrm{Fe}-\mathrm{Si}-\mathrm{Al}$ 系合金の初期酸化膜

\begin{tabular}{l|l|l}
\hline \hline 供試合金 & \multicolumn{1}{|c|}{$700^{\circ} \mathrm{C}(5 \mathrm{~min})$} & \multicolumn{1}{|c}{$1000^{\circ} \mathrm{C}(2 \mathrm{~min})$} \\
FSA 1 & $\alpha-\mathrm{Fe}_{2} \mathrm{O}_{3}+\mathrm{Fe}_{3} \mathrm{O}_{4}+\mathrm{SiO}_{2}$ & $\alpha-\mathrm{Fe}_{2} \mathrm{O}_{3}+\mathrm{Fe}_{3} \mathrm{O}_{4}+\mathrm{SiO}_{2}$ \\
FSA 2 & $\alpha-\mathrm{Fe}_{2} \mathrm{O}_{3}+\mathrm{SiO}_{2}$ & $\alpha-\mathrm{Fe}_{2} \mathrm{O}_{3}+\mathrm{Fe}_{3} \mathrm{O}_{4}+\mathrm{Al}_{2} \mathrm{O}_{3}$ \\
FSA 3 & $\alpha-\mathrm{Fe}_{2} \mathrm{O}_{3}+\mathrm{Al}_{2} \mathrm{O}_{3}$ & $\alpha-\mathrm{Fe}_{2} \mathrm{O}_{3}+\mathrm{Al}_{2} \mathrm{O}_{3}$ \\
$\mathrm{FSA} \mathrm{4}$ & $\alpha-\mathrm{Fe}_{2} \mathrm{O}_{3}+\mathrm{SiO}_{2}$ & $\alpha-\mathrm{Fe}_{2} \mathrm{O}_{3}+\mathrm{SiO}_{2}$ \\
FSA 5 & $\alpha-\mathrm{Fe}_{2} \mathrm{O}_{3}+\mathrm{SiO}_{2}$ & $\alpha-\mathrm{Fe}_{2} \mathrm{O}_{3}+\mathrm{Al}_{2} \mathrm{O}_{3}$ \\
FSA 6 & $\alpha-\mathrm{Fe}_{2} \mathrm{O}_{3}+\mathrm{Al}_{2} \mathrm{O}_{3}$ & $\alpha-\mathrm{Fe}_{2} \mathrm{O}_{3}+\mathrm{Al}_{2} \mathrm{O}_{3}$ \\
FSA 7 & $\alpha-\mathrm{Fe}_{2} \mathrm{O}_{3}+\mathrm{SiO}_{2}$ & $\alpha-\mathrm{Fe}_{2} \mathrm{O}_{3}+\mathrm{SiO}_{2}$ \\
FSA 8 & $\alpha-\mathrm{Fe}_{2} \mathrm{O}_{3}+\mathrm{SiO}_{2}$ & $\alpha-\mathrm{Fe}_{2} \mathrm{O}_{3}+\mathrm{Al}_{2} \mathrm{O}_{3}$ \\
FSA 9 & $\alpha-\mathrm{Fe}_{2} \mathrm{O}_{3}+\mathrm{Al}_{2} \mathrm{O}_{3}$ & $\alpha-\mathrm{Fe}_{2} \mathrm{O}_{3}+\alpha-\mathrm{Al}_{2} \mathrm{O}_{3}$ \\
\hline
\end{tabular}

なかった FSA 1 あるいは FSA 2 の $700^{\circ} \mathrm{C}$ 酸化初期に は, 非晶質 $\mathrm{SiO}_{2}$ 皮膜が $\alpha-\mathrm{Fe}_{2} \mathrm{O}_{3}$ を主体とした酸化鉄 皮膜の内側に合金表面に接して形成していた。すなわち 約 $1 \% \mathrm{Si}$ を含んだ $\mathrm{Fe}-\mathrm{Si}-\mathrm{Al}$ 系合金の $700^{\circ} \sim 1000^{\circ} \mathrm{C}$ 酸化に際しては， $\mathrm{Al}$ 含量が約 $6 \%$ というように多いか， あるいは約 $2 \%$ 程度でも酸化温度が $1000^{\circ} \mathrm{C}$ ほどにな ると合金表面に接して耐酸化性皮膜乞して $\mathrm{Al}_{2} \mathrm{O}_{3}$ を主 体としたものを形成し，低 $\mathrm{Al}$ 含量か酸化温度の低い場 合には $\mathrm{SiO}_{2}$ の非晶質薄膜が耐酸化性皮膜としてその形 成を見た。な初期酸化膜中の $\mathrm{Al}_{2} \mathrm{O}_{3}$ 皮膜は $700^{\circ} \sim$ $1000^{\circ} \mathrm{C}$ ではいまだその結晶もきわめて微細で, 回折像 の与えた二, 三の回折環からその種類が $\gamma$-あるいは $\alpha$ $\mathrm{Al}_{2} \mathrm{O}_{3}$ かを判別するのは困難であった。

(2) 約 3\% Si-AJ-Fe 系合金 (FSA 4 6)

約 $3 \% \mathrm{Si}$ と同時に約 1 6\% Al を含有した FSA $4 \sim 6$ の空気中 $700^{\circ} \mathrm{C}$ および $1000^{\circ} \mathrm{C}$ 初期酸化膜はいず れも $\alpha-\mathrm{Fe}_{2} \mathrm{O}_{3}$ を主体とした酸化物からなり, FSA 5 の $1000^{\circ} \mathrm{C}$ および $\mathrm{FSA} 6$ の $700^{\circ} \mathrm{C}$ および $1000^{\circ} \mathrm{C}$ 初期酸 化膜は酸化鉄以外に合金表面に接して $\gamma$ - あるい注 $\alpha$ $\mathrm{Al}_{2} \mathrm{O}_{3}$ 結晶皮膜の形成を見た。またこのように $\mathrm{Al}_{2} \mathrm{O}_{3}$ 皮 膜の形成が電子回折的に検出できなかった FSA 4 の $700^{\circ} \mathrm{C}$ ならびに $1000^{\circ} \mathrm{C}$ 酸化膜および FSA 5 の $700^{\circ} \mathrm{C}$ 初期酸化膜中には $\alpha-\mathrm{Fe}_{2} \mathrm{O}_{3}$ 皮膜の内層に非晶質 $\mathrm{SiO}_{2}$ 皮 膜の存在が認められた(第 2 表)。

\section{(3) 約 6\% Si-Al-Fe 系合金 (FSA 7 9)}

約 $6 \% \mathrm{Si}$ と同時に約 1\% $\mathrm{Al}$ を含有した FSA 7 は $700^{\circ} \mathrm{C}$ 打よび $1000^{\circ} \mathrm{C}$ 酸化膜とも, その電子回折透過像 は $\alpha-\mathrm{Fe}_{2} \mathrm{O}_{3}$ 結晶の面間隔に相当する回折環を示し, FSA 1 および 4 と同じく $1 \%$ ほどの $\mathrm{Al}$ 含有合金では空気 中酸化初期において表面には $\mathrm{Al}_{2} \mathrm{O}_{3}$ 皮膜の成長を認める ことができなかった。しかしながら FSA 1 および 4 と 同じく $\alpha-\mathrm{Fe}_{2} \mathrm{O}_{3}$ 皮膜の内側に，合金表面に接して非晶 質 $\mathrm{SiO}_{2}$ からなる薄膜の形成が認められた。FSA 8 にお いては $700^{\circ} \mathrm{C}$ 打よび $1000^{\circ} \mathrm{C}$ 初期酸化膜とも前述各合 金と同様 $\alpha-\mathrm{Fe}_{2} \mathrm{O}_{3}$ を主体とした皮膜からなっていたが， その内側の合金表面に接して $700^{\circ} \mathrm{C}$ の場合には $\mathrm{SiO}_{2}$ の 非晶質皮膜のまた $1000^{\circ} \mathrm{C}$ の場合には $\mathrm{Al}_{2} \mathrm{O}_{3}$ 皮膜の 形成が見られた。FSA 9 では $700^{\circ} \mathrm{C}$ および $1000^{\circ} \mathrm{C}$ 初 期酸化膜が敢きを異にし， $700^{\circ} \mathrm{C}$ の場合には $\alpha-\mathrm{Fe}_{2} \mathrm{O}_{3}$ を主体としたが, $1000^{\circ} \mathrm{C}$ の場合にはむしろ $\alpha-\mathrm{Al}_{2} \mathrm{O}_{3}$ を 主体とした酸化物からなりたっていた。

すなわち約 1～6\% Si と同時に約 1～7\% Al を含ん だ $\mathrm{Fe}-\mathrm{Si}-\mathrm{Al}$ 系合金はいずれも, $700^{\circ} \sim 1000^{\circ} \mathrm{C}$ 空気中 酸化初期に $\mathrm{Al}_{2} \mathrm{O}_{3}$ 皮膜か, または非晶質の $\mathrm{SiO}_{2}$ 皮膜と いう低電気伝導度の耐酸化性皮膜のいずれかによって合 金表面が被覆されることが明らかとなった。しかも合金 中の $\mathrm{Al}$ 含量が $6 \%$ 程度では $700^{\circ} \mathrm{C}$ で，また $2 \sim 3 \%$ でも $1000^{\circ} \mathrm{C}$ で合金表面に接して $\mathrm{Al}_{2} \mathrm{O}_{3}$ 皮膜の生成を 見，その際 $\mathrm{SiO}_{2}$ 皮膜の形成が認められなかったが，こ れは酸化初期に合金表面が $\mathrm{Al}_{2} \mathrm{O}_{3}$ 皮膜で緻密に被覆され ると，これら皮膜を通しての $\mathrm{Si}$ の表面への拡散が著し く抑制されたためと思われる。

\section{4. 高温酸化スケールとその構造}

\section{(1) 約 1\% Si-Al-Fe 系合金 (FSA 1 3)}

FSA 2 を空気中で $1100^{\circ} \mathrm{C}$ に $7 \mathrm{hr}$ 加熱すると黑色の 比較的厚い酸化スケールで被覆され，その外層部を䟝離 すると内層はスケールの一部溶融した痕跡を示すガラス 状皮膜とそ.の内層に赤褐色の薄膜の存在が認められた。 このスケールを外層部と内層部に大別して X 線回折し た結果が第 1 図であり，またスケール断面組織を写真 1 に示す。本合金は FSA 1 に比して Al 含量が多いにも かかわらず, そのスケール構造は類似して 3 層からなり, 内層には $1100^{\circ} \mathrm{C}$ 酸化ですでに $\mathrm{FeO}$ と $\mathrm{Fe}_{2} \mathrm{SiO}_{4}$ の共 晶層が形成され，初期酸化膜 $\left(1000^{\circ} \mathrm{C}\right)$ に見出された 


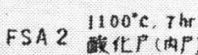

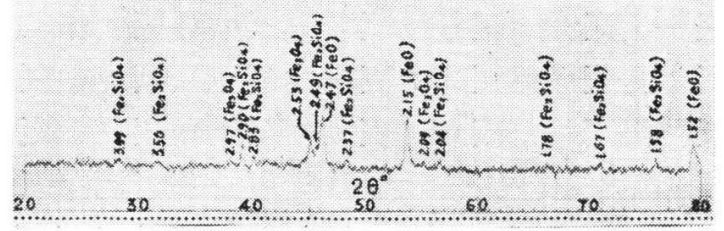

第1図 $0.82 \% \mathrm{Si}-2.36 \% \mathrm{Al}-\mathrm{Fe}$ 合金の $1100^{\circ} \mathrm{C}$ 酸化スヶールの X 線回折像

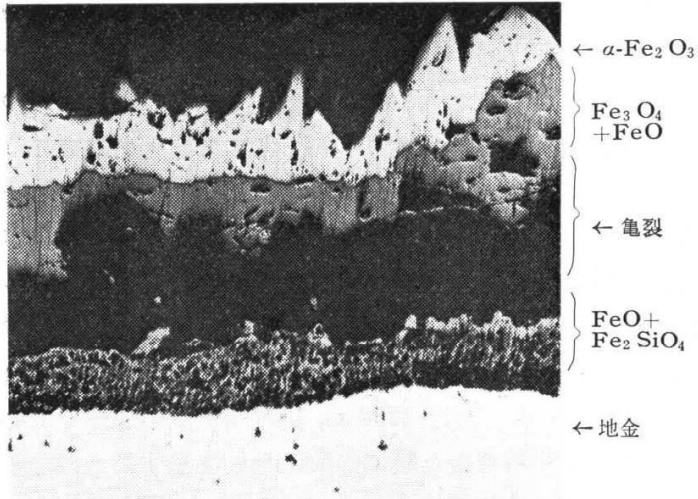

写真 $10.82 \% \mathrm{Si}-2.36 \% \mathrm{Al}-\mathrm{Fe}$ 合余老 $1100^{\circ} \mathrm{C}$ 一 $7 \mathrm{hr}$ 酸化したょきのスケール断面 $(\times 140)$

$\mathrm{Al}_{2} \mathrm{O}_{3}$ 上りなる性别の酎熱性保護層の形成を哂的ること がだきなかった。主た本合金の $1200^{\circ} \mathrm{C}, 3 \mathrm{hr}$ 酸化スケー ル外尿加ら $\alpha-\mathrm{Fe}_{2} \mathrm{O}_{3}, \mathrm{Fe}_{3} \mathrm{O}_{4}, \mathrm{FeO} z \mathrm{Fe}_{2} \mathrm{SiO}_{4}$ の共晶

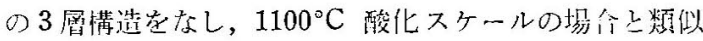

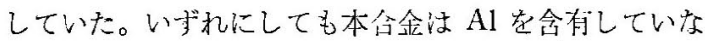
い䄪 $1 \% \mathrm{Sj}-\mathrm{Fe}$ 系合金之同椂の高温酸化挙動を示し， $1100^{\circ} \mathrm{C}$ 酸化ですでにスケール内贋には $\mathrm{FeO}$ と $\mathrm{Fe}_{2} \mathrm{SiO}_{4}$ 相の共晶層方形成され，この酸化温度はこ秃ら両相の共 晶点 (約 $1170^{\circ} \mathrm{C}$ ) 以下の温度であるが，かかる温度で の長時閒使用法避けるべきごる。

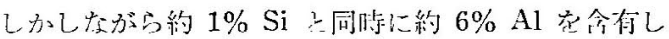

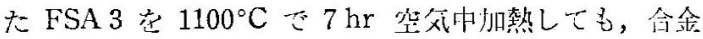
表面注きわわて薄い赤裸位スケールで被覆され，しかも

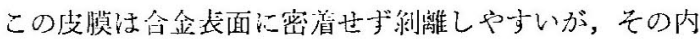
側の合金表面心接しては干涉也呈する薄膜の形成を

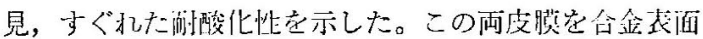
から剩離して，企スケールの X 線回折定試みた絬果，

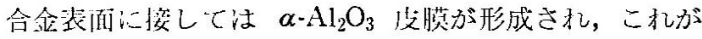
言温での的酸化去に奇与していることが判明した。した がって陖化猃スケール層発発達せず，わずかに $\alpha-\mathrm{Fe}_{2} \mathrm{O}_{3}$

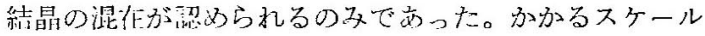

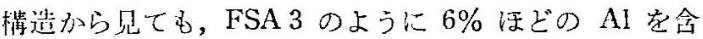
有す狄访，Si 含有が $1 \%$ でも $1100^{\circ} \mathrm{C}$ 程度での使用に は十分矿えることがわかる。しかし本全食も $1200^{\circ} \mathrm{C}$ K
$3 \mathrm{hr}$ 空気中加熱保持すると，相当発達したスケール層こ 被覆され，スケール内層中に $\mathrm{FeO}$ 相とともに $\mathrm{Fe}_{2} \mathrm{SiO}_{4}$ 相が尘成さ扎，これら雨相の其晶点以上の扣熱のたるス ケールが融解して酸化鉄スケールの成唇考伴う酸化が著 しく促進された。しかも $1100^{\circ} \mathrm{C}$ 酸化で全企主面に接し

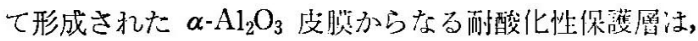

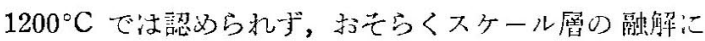
上り溶假除志されたものと思和れる。ただスケール中: 法 Spinel 型酸化物 $\left(\mathrm{FeAl}_{2} \mathrm{O}_{4}\right)$ らしきものふらなる相の 形成が忍引られるが， $\mathrm{FeO}, \mathrm{Fe}_{2} \mathrm{SiO}_{4}$ 両相の形成下でこ れら Spinel 層がどの程度合金の耐高温酸化性に奇与し ているふ疑開である。

\section{(2) 約 3\% Si-Al-Fe 系合金 (FSA 4 6)}

$3 \% \mathrm{Si}$ 々同時に 1\% Al 它えだ FSA 4 の $1100^{\circ} \mathrm{C}$, $7 \mathrm{hr}$ 酸化では，合金表面は黑色の比較的厚化したスケー ルで被覆され，約 $3 \% \mathrm{Si}-\mathrm{Fe}$ 合金の同条件酸化 てはるかに酎酸化性が劣化したが，こ机はさきに三島， 椙山文が Fe-Si-Al 系全金の耐高温酸化限界温度が同 $\mathrm{Si}$

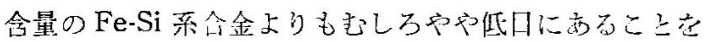

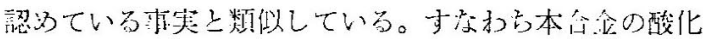

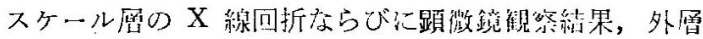

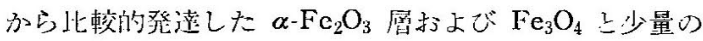
$\mathrm{FeO}$ 含えだ酸化銠層，ならでに $\mathrm{FeO}$ 相上 $\mathrm{Fe}_{2} \mathrm{SiO}_{4}$ 相

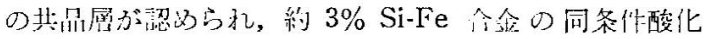
スケール内䚄に認められたような $\mathrm{SiO}_{2}$ ( $\alpha$-qualtz む上 び $\alpha$-cristobalite) 加らなる耐酸化性保濩層总梌出する こと沈できなかった。 $1200^{\circ} \mathrm{C}, 3 \mathrm{hr}$ 酸化ても本全金のス ケール中には $\mathrm{FeO}$ 上ともに $\mathrm{Fe}_{2} \mathrm{SiO}_{4}$ の生成学見，酎酸 化临は少化した。

また秎 $3 \% \mathrm{Si}$ と同脂に的 $3 \%$ の Al 艺含们したFSA

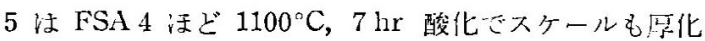
しなかった。このスケールのX X 線回折絬果はFSA 4 と

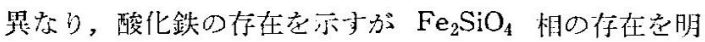
眡に示さなかった。しかし $1200^{\circ} \mathrm{C}, 3 \mathrm{hr}$ 酸化ではスケ 一ル層が厚化し，そのスケール叫に活 $\mathrm{FeO}$ 相とともに

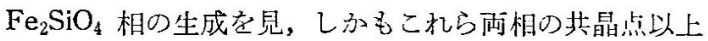
のためかスケール層の融解が涊められ， $\mathrm{Al}_{2} \mathrm{O}_{3}$ あるいは $\mathrm{SiO}_{2}$ などよりなる耐酸化性保蓝畨も愉出されなかった。

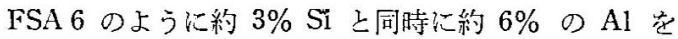
含えだ全金怄， $1100^{\circ} \mathrm{C}, 7 \mathrm{hr}$ 空気中加熱でもきわめてす ぐれだ耐高温酸化州老小し表而が白赤色の溥いスケール で被覆された。との X 線回折結果梳微細な $\alpha-\mathrm{Al}_{2} \mathrm{O}_{3}$ 結

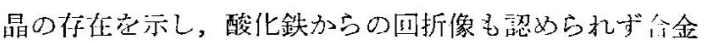
が $\alpha-\mathrm{Al}_{2} \mathrm{O}_{3}$ 友膜により保護されていること宗した（第 2 図)。写真 2 はこれら $\alpha-\mathrm{Al}_{2} \mathrm{O}_{3}$ 皮膜が全金堂被覆して いるところである。しかしながら本合金も $1200^{\circ} \mathrm{C}$ 、゙ 全くその酸化举動を異にし，全金は灰黑色の愿化スケー 


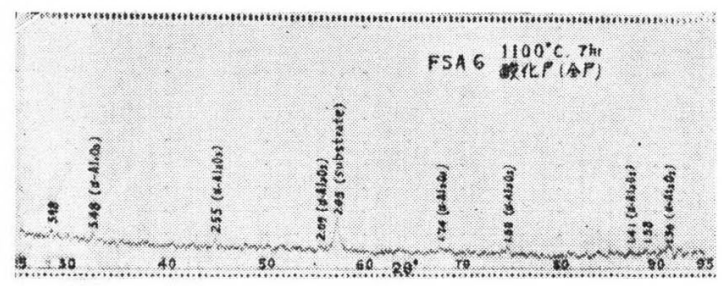

第 2 图 3.16\% Si-6.07\% Al-Fe 合金の $1100^{\circ} \mathrm{C}$ 酸化スケールの X 線回折像

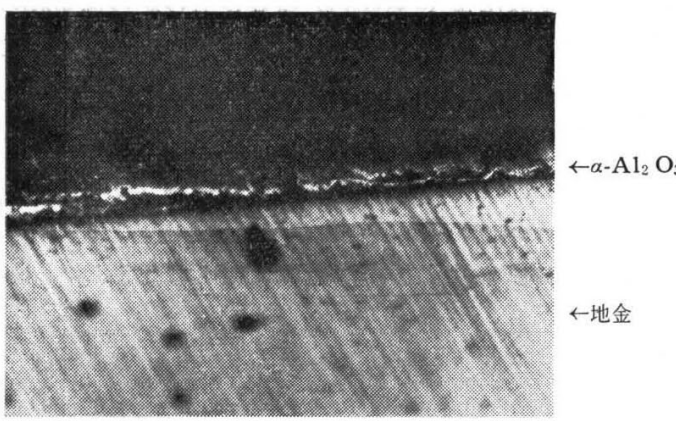

写真 $23.01 \% \mathrm{Si}-6.07 \% \mathrm{Al}-\mathrm{Fe}$ 合金を $1100^{\circ} \mathrm{C}$ で $7 \mathrm{hr}$ 酸化したときのスケールの断面 $(\times 250)$

ルで被稪された。その原因はFSA 1〜5 と同じくスケー ル灼愿に形成した $\mathrm{FeO}$ と $\mathrm{Fe}_{2} \mathrm{SiO}_{4}$ 両相の形成とその共 晶点以上の打熱によるスケールの融解に基つくことが明 らねとなった。

(3) 的 6\% Si-Al-Fe 系合金 (FSA 7 9)

約 $6 \% \mathrm{Si}$ とともに䄪 1\% Al を含有した FSA7を $1100^{\circ} \mathrm{C}, 7 \mathrm{hr}$ 空気中加熱すると表面が扊色の薄いスケー ルで被覆され，その内側には茶褐色の皮膜が形成してい るがここのチールを外層部と内層部に大別採取後 $\mathrm{X}$ 線回折すると第3図のような回折像が得られる。すなわ ちスケールは $\alpha \cdot \mathrm{Fe}_{2} \mathrm{O}_{3}$ と $\mathrm{Fe}_{3} \mathrm{O}_{4}$ を主体とした酸化物か

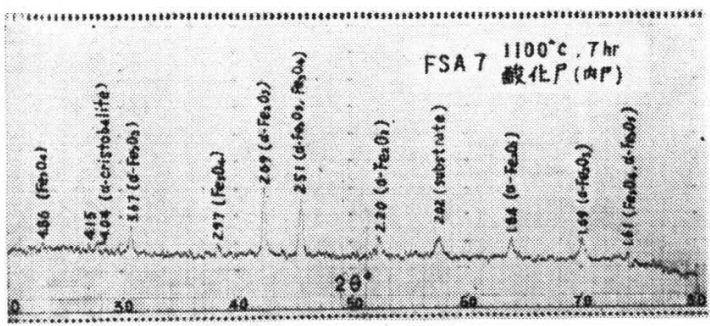

3 図 $5.82 \% \mathrm{Si}-1.35 \% \mathrm{Al}-\mathrm{Fe}$ 合金の $1100^{\circ} \mathrm{C}$ 酸化スタールの X 線回折像

らなり，その㑛本全金の $700^{\circ} \mathrm{C}$ おび $1000^{\circ} \mathrm{C}$ 初期酸 化面に認められた非晶質 $\mathrm{SiO}_{2}$ 皮膜が結晶化して常温で は低温型の $\alpha$-cristobalite および $\alpha$-qualtz となってい ることを示す一，二の回折線が認められた。本俗金が $1100^{\circ} \mathrm{C}$ の長時閒酸化で良い耐酸化性を示す原因はかか る低電父伝導废の $\mathrm{SiO}_{2}$ 支膜の保護作用による結果であ
ることが判明した。すなわち約 $6 \%$ ほどの Si を含えだ 本会金は同 $\mathrm{Si}$ 含量の Fe-Si 系合金と同じ酸化挙動を示 し Al 含有の影響は認められない。このように $1100^{\circ} \mathrm{C}$ ではする゙れた耐酸化性を示した本含金も $1200^{\circ} \mathrm{C} ， 3 \mathrm{hr}$ 空気中酸化では試料もとの原型をとどめないほど酸化 し，スケール層は厚化とともに融解をした。X 線回折結 果，スケール外層部からを $\alpha-\mathrm{Fe}_{2} \mathrm{O}_{3}, \mathrm{Fe}_{3} \mathrm{O}_{4}$ とともに $\mathrm{Fe}_{2} \mathrm{SiO}_{4}$ 相が湌出され，約 $6 \% \mathrm{Si}-\mathrm{Fe}$ 合金の同条作酸化 スケール3゙ と同じく $\mathrm{FeO}$ 相は検出されなかったが，耐 酸化性皮膜としての $\mathrm{SiO}_{2}$ 層も消失していた。

また FSA 8 および 9 のように約 $6 \% \mathrm{Si}$ と同時にそ れぞれ約 $3 \%$ および $7 \%$ の Al を含有しても，その $1200^{\circ} \mathrm{C}, 3 \mathrm{hr}$ 酸化ではいずれも厚化スケールが形成され 耐高温酸化性が改善されなかった。しかもこ机らスケー ル内曆にはいずれも $\mathrm{FeO}$ とともに $\mathrm{Fe}_{2} \mathrm{SiO}_{4}$ 相が検出さ れ，加熱昷度がこれら両相の共晶点以上のためスケール 愿が融解し耐酸化は劣化することが明らかとなった。す なわち 1〜7\% Al と同時に約 1〜6\% Si を含んだこれ 万 Fe-Si-Al 系合金は $1200^{\circ} \mathrm{C}$, 長時問空気中加熱ではい ずれも Fe-Si 系合金と類似の酸化挙動を示すようになる し、また $\mathrm{Fe}-\mathrm{Al}$ 系合金の方が $\mathrm{Fe}-\mathrm{Si}$ 系合金よりも一 般に耐高温酸化限界温度が高い2）のであり，FSA 3，6 あるいは 9 などのように約 6〜7\% ほどの Al を含え だ合金に Si を添加することは避けるのが賢明のようで ある。

\section{5. 䊅}

約 1〜 6\% $\mathrm{Si}$ と同時に約 1〜7 Al を含有した 9 種の $\mathrm{Fe}-\mathrm{Si}-\mathrm{Al}$ 系合金について, 空父中 $700^{\circ} \mathrm{C}$ および $1000^{\circ} \mathrm{C}$ で合金表面に形成した初期酸化㨫を $1 \mathrm{cc} \mathrm{Br}_{2} / 50 \mathrm{cc}$ $\mathrm{CH}_{3} \mathrm{OH}$ を用いて合金から制離し電子回折透過観察した。 また $1100^{\circ} \mathrm{C}, 7 \mathrm{hr}$ ならびに $1200^{\circ} \mathrm{C}, 3 \mathrm{hr}$ 空気中加熱 保持した合金の表面生成スケールを X 線回折と断面組 織の顕微鏡観察により究明した。その結果判明した事実 を次に列挙する。

(1) いずれの合金も $700^{\circ} \mathrm{C}$ および $1000^{\circ} \mathrm{C}$ での空 気巾酸化初期に合金表面に接して $\mathrm{Al}_{2} \mathrm{O}_{3}$ か $\mathrm{SiO}_{2}$ のいず れかからなる酸化膜の形成を認めた。その外層の酸化物 は末として rhombohedral 型の $\alpha-\mathrm{Fe}_{2} \mathrm{O}_{3}$ 結晶からなり たっていた。

(2) 約 $6 \% \mathrm{Si}-\mathrm{Al}-\mathrm{Fe}$ 系合金を除いて䄪 1 3\% Al を含有した合金（FSA 1〜6）には同 $\mathrm{Si}$ 含有の Fe-Si。 系合金よりも $1100^{\circ} \mathrm{C}$ 酸化スケールの厚化を見るものが あったが，これら厚化スケール内層にはいずれも $\mathrm{FeO}$ および $\mathrm{Fe}_{2} \mathrm{SiO}_{4}$ の両相が X 線回折により検出された。 すなわら約 1〜3\% Si-Al-Fe 系合金に $1100^{\circ} \mathrm{C}$ ですぐれ た耐酸化性を与えるには $3 \%$ 以上約 $6 \%$ ほどの $\mathrm{Al}$ 添加して， $\alpha-\mathrm{Al}_{2} \mathrm{O}_{3}$ よりなる耐酸化性皮膜を合金表面に 
形成させる必要がある。

(3) 約 $6 \% \mathrm{Si}-\mathrm{Al}-\mathrm{Fe}$ 合金 (FSA 7) は $1100^{\circ} \mathrm{C}$ で すぐれた耐酸化性を示したが，これは $\mathrm{SiO}_{2}$ 皮膜の保護 作用によることが判明した。また約 1〜3\% Si-6\% Al$\mathrm{Fe}$ 系合金（FSA 3 および 6) が $1100^{\circ} \mathrm{C}$ で良い耐酸化 性を示した原因は㑒金表面を被覆した $\alpha-\mathrm{Al}_{2} \mathrm{O}_{3}$ 汥膜に 基づいていた。

(4) 本研究に用いた Fe-Si-Al 系众金は, いずれも $1200^{\circ} \mathrm{C}, 3 \mathrm{hr}$ 空父中加熱により厚化したスケールで被覆 されたが，これら耐酸化性劣化の原因は Fe-Si 系合金 の場合と同様, $\mathrm{FeO}$ および $\mathrm{Fe}_{2} \mathrm{SiO}_{4}$ 両相の生成と, 共 晶点 (約 $1170^{\circ} \mathrm{C}$ ) 以上の加熱によるスケール層の融解
と，てれに伴う $\mathrm{SiO}_{2}$ あるい注 $\mathrm{Al}_{2} \mathrm{O}_{3}$ などからなる耐酸 化州:皮膜の融解消失に基づくことが明らかとなった。

(5) 約 $6 \% \mathrm{Al}-\mathrm{Fe}$ 今金ではその耐问温酸化限界温 度が約 $1300^{\circ} \mathrm{C}$ 以上にあり2), FSA $3 ， 6$ 抢よ゙ 9 の上 うに約 6〜7\% Al を含んだ全金に約 1〜6\% Si を同時 に添加与ることは， $1200^{\circ} \mathrm{C}$ での空父中酸化が著しく進 行するところから，耐间温酸化性に対して气しろ有害で 避けるのが堅明である。（昭和 34 年 9 月 8 П受理）

\section{文献}

1) E. Scheil \& K. Kiwit: Arch. Eisenhüttenw., 9, 405 (1936)

2) 三島，相山：鉄と鋼，36，184（1950)

3) 椙山, 中山：日本金属学会誌, 23,468 (1954)

\section{muแuแuแuแuแuแuแ \\ 技術トピック}

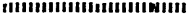

\section{油田用管類の応力度食裂}

油田で起る応搱食龟裂には 2 程類ある。Sour Oil によるものと Sweet Oil によるものとである。これを 防ぐに法次の 3 方法が考えられる。（1）応力腐食重裂 を起さない材料の使用。（2）応力㢈食亀裂を生ずる忉 料を用い応打よび硬度を莗裂を発生しない限度内で使 用专る。（3）環境の性質を变える。鋼材で応力腐食黾 裂を尘じないものはないので第 1 の方法法だめである。 第3の广法としては抑制刜の添加があるが実用的でな い。沛えに鸽 2 の方法すなわち各種鋼材の各種環境にお ける応抔食癿裂を生じない硬度一応うの限度を探究す ることが大切である。往来は磨いた Beam 試験片を用 いて試験が行なわれていたが，この方法では硬度一応力 の限度を決定するには成績のバラッキが多くて不適であ る。今回の試験ではノッチをつけた○リングを用い煊閒 の大いさによって応力を加減した。このう法では成績の 再現性がきわめて良い。Sour Oil に対する試験のため 歪老弾性限歪の $100,80,60 ， 40,20 ， 10 \%$ (変形率と 呼ぶ）の 6 種とし各変形㳯ごとに 4 枚の試験片を用い $\mathrm{H}_{2} \mathrm{~S}$ 飽和 $(3,000 \mathrm{ppm})$ の $5 \%$ 食塭水に浸漬して亀裂発 生までの時間を計測した。使用材料は N-80 (0.46C， $1.0 \mathrm{Mn}, 0.2 \mathrm{Mo})$ で硬度は Rockwell C 33〜35 であ る。変形率 $20,10 \%$ ものでは破壊しなかった。成縝を 次図中に示す。次に $\mathrm{N}-80$ と J-55 $(0.45 \mathrm{C}, 0.7 \mathrm{Mn}$, <0.1 Mo） に各種の熱処理を行なったものを各種の变 形率のもとに飽和 $\mathrm{H}_{2} \mathrm{~S}$ 食塩水中に浸漬して硬度一応力 限を求めた。重裂を生じない限度は硬度37のとき变形率 $20 \%$ 以下，硬度 31 のとき変形率 $60 \%$ 以下，硬度 23 以 下ではいかなる応抗も腐食亀裂は生じない。Sweet Well で故障を起す原因について調查したところ応力腐 食莗裂を生じた油田で法必ず微量でも $\mathrm{H}_{2} \mathrm{~S}$ が検出され，
$\mathrm{N}-80$ 硬度 Rockwell $33-35$ (C)

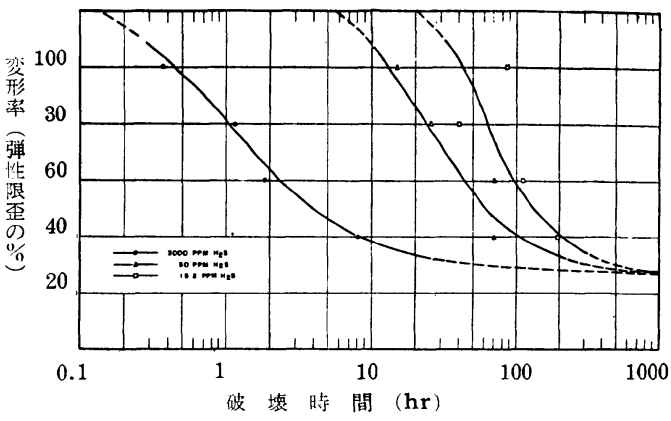

$\mathrm{H}_{2} \mathrm{~S}$ 濃度, 変形率, 破壊時間の関係

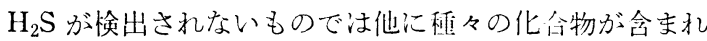
ていてもあるい法ての液中で材料を㓌極として通電して も故障を生じないことが明らかとなった。それで $\mathrm{H}_{2} \mathrm{~S} の$ 濃度と応力屡食黾裂の関係学調查与るため $\mathrm{H}_{2} \mathrm{~S} 50 \mathrm{ppm}$, $15.2 \mathrm{ppm}$ 抢よびそれ以下でノッチ付 ○リング試験を行 なった。その成績は上図に示した。図に明らかのように $\mathrm{H}_{2} \mathrm{~S}$ の含量 $15.2 \mathrm{ppm}$ あるい注それ以下で変形萃 $40 \%$ でも応力腐食渑裂を発生する。

R. L. McGlasson \& W.D. Greathouse: Corrosion, 15, No. 8, $437 \mathrm{t} \sim 442 \mathrm{t}$ (1959) Aug.

(E.F.)

\section{採油用海上作業台が示すメキシコ湾海上の 炭素鋼の腐食度}

最近メキシコ湾の海上に設けられた石油採取用作業台 の 9 年注ど経過しているものを精しく調べた。その結 果，その $24^{\prime \prime}$ 外径の管柱の腐食速度は平均水面から 0.5 〜 $1.5 \mathrm{ft}$ 上少で最低值の $0.002 \mathrm{in} / \mathrm{yr}$ を示し $(0.5 \mathrm{ft}$ 下 祁は $0.005 \mathrm{in} / \mathrm{yr}) 9.5 \sim 10 \mathrm{ft}$ 上蔀で最大㑲の $0.21 \mathrm{in} /$ yr (11.5 ft 上方で注 $0.017 \mathrm{in} / \mathrm{yr})$ を示年ことが判明し た。

D. Patterson : Corrosion, 15, No. 8, 103 (1959) Aug.

(M. H. ) 